C. PALOMO*, A. L. PALOMO*, F. PALOMO, A. MiElgo (UNIVERSidAd DEL PAís VASCo, APARTADO, SPAIN)

Soluble $\alpha$-Amino Acid Salts in Acetonitrile: Practical Technology for the Production of Some Dipeptides Org. Lett. 2002, 4, 4005-4008, DOI: 10.1021/ol020136x.

\title{
Dipeptides Synthesis by Using Phosphazene Bases to Enhance the Solubility of Amino Acids
}

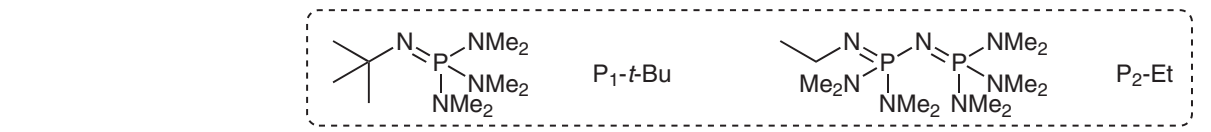

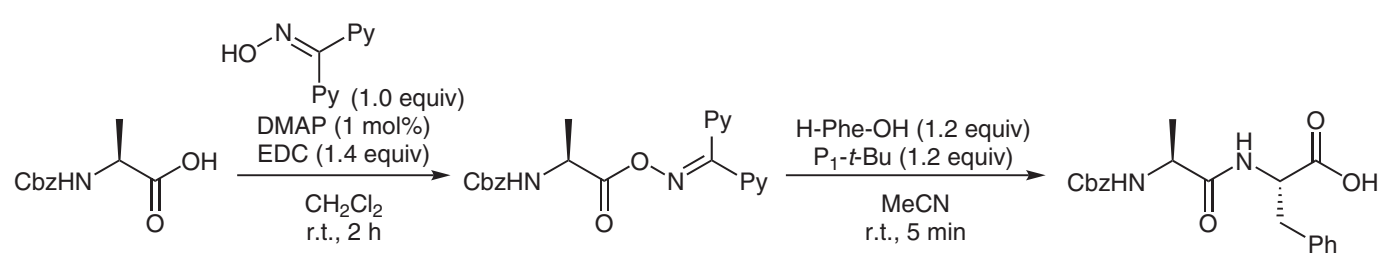

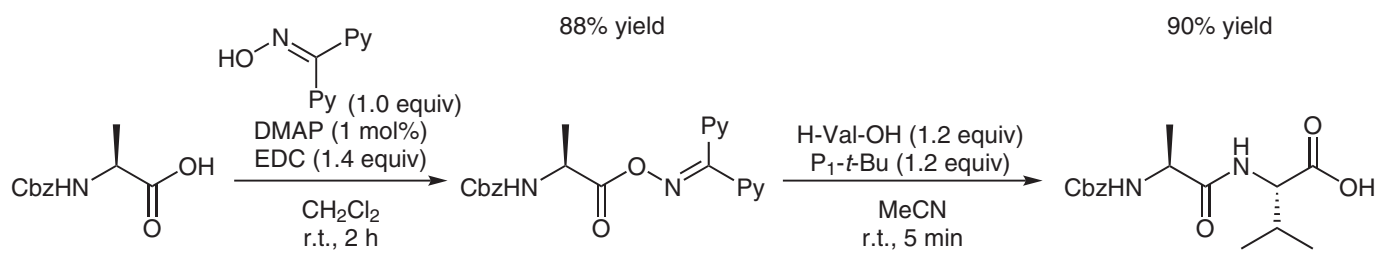

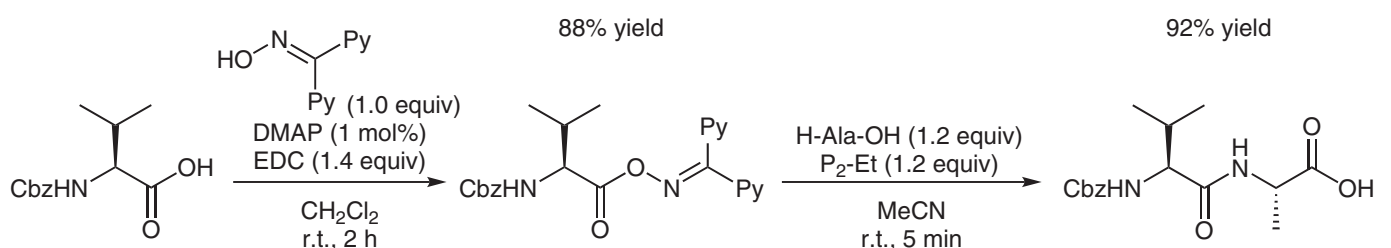

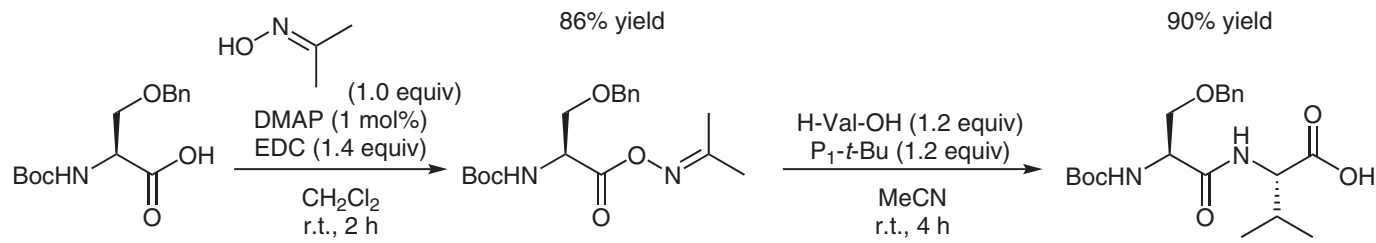

$$
\begin{aligned}
& \text { (1.2 equiv) }
\end{aligned}
$$

\section{Category}

Peptide Chemistry

\section{Key words}

amino acids

phosphazene bases

ketone esters

dipeptides

solubilization

\section{Synfact}

Significance: $\alpha$-Amino acids are widely used in organic chemistry. However, the low solubility of free amino acids causes some problems in organic synthesis. In 2002, a method to enhance the solubility of amino acids in organic media by using phosphazene bases was reported.
Comment: Some dipeptides can be synthesized from free amino acids in acetonitrile when phosphazene bases are used to increase solubility. The yields of the target peptides are excellent. This strategy might be useful in other reactions involving $\alpha$-amino acids. 